\title{
Life-Cycle Thinking in Inquiry-Based Sustainability Education - Effects on Students' Attitudes towards Chemistry and Environmental Literacy
}

Marianne Juntunen ${ }^{\star 1}$ And Maija Aksela ${ }^{2}$

$\approx$ The aim of the present study is to improve the quality of students' environmental literacy and sustainability education in chemistry teaching by combining the socio-scientific issue of life-cycle thinking with inquiry-based learning approaches. This case study presents results from an inquiry-based life-cycle thinking project: an interdisciplinary teaching model designed by chemistry teachers. The strength of the project is that upper-secondary students $(\mathrm{N}=105)$ are allowed to investigate the life cycle of an optional product based on their own interest. Studentcentred teaching methods are suggested to promote the students' interest in studying. The research question was: How does an inquiry-based life-cycle thinking project in chemistry education affect students' chemistry attitudes and environmental literacy? The research methods used included surveys and semi-structured interviews. The study shows that the project positively affected students' attitudes towards chemistry learning: they valued the independent and collaborative learning setting. The changes in the students' environmental literacy were evident in their new realisations: they emphasised the importance of environmental protection and recycling, but perceived that changing their own behaviour is still difficult. The inquiry-based teaching of life-cycle thinking can be seen as an effective approach to more motivating and sustainable chemistry education. Further research should address the kinds of knowledge outcomes that this type of inquiry-based life-cycle teaching creates in students. Furthermore, other useful approaches to teaching sustainable development in chemistry lessons should be shared.

Keywords: Attitudes; Chemistry learning; Environmental literacy; Inquiry-based learning; Life-cycle thinking

$1{ }^{*}$ Corresponding Author. Unit of Chemistry Teacher Education, Department of Chemistry, University of Helsinki, Finland marianne.juntunen@helsinki.fi

2 Unit of Chemistry Teacher Education, Department of Chemistry, University of Helsinki, Finland 


\section{Življenjski krog izdelkov in učenje z raziskovanjem za trajnostni razvoj - vpliv na odnos učencev do kemije in okoljska pismenost}

Marianne Juntunen* And Maija Aksela

$\propto$ Cilj raziskave je izboljšanje kakovosti odnosa dijakov do kemije, njihove okoljske pismenosti in do trajnega izobraževanja s pomočjo združevanja socionaravoslovnih vsebin, tj. razmišljanja o življenjskem krogu izdelkov, in pristopov učenja $\mathrm{z}$ raziskovanjem. $\mathrm{V}$ tej študiji primera so predstavljeni izsledki projekta o učenju $\mathrm{z}$ raziskovanjem pri uporabi konteksta, povezanega $\mathrm{z}$ življenjskim krogom izdelkov. Projekt so kot interdisciplinarni model poučevanja oblikovali učitelji kemije. Njegova prednost je, da lahko srednješolci $(\mathrm{N}=105)$ raziskujejo življenjski krog poljubnega predmeta oz. izdelka glede na želje ali interes, saj naj bi metode poučevanja, ki v središče postavljajo učenčeve interese, spodbujale njihovo zanimanje za učenje neke vsebine. Raziskovalno vprašanje je bilo, kako pristop učenja $\mathrm{z}$ raziskovanjem $\mathrm{z}$ uporabo konteksta o življenjskem krogu izdelkov pri pouku kemije vpliva na odnos učencev do kemije in na njihovo okoljsko pismenost. Podatki so bili pridobljeni z anketiranjem in s polstrukturiranimi intervjuji. Študija je pokazala, da je učni pristop, uporabljen v projektu, pozitivno vplival na odnos dijakov do učenja kemije; pozitivno so ocenili individualno in sodelovalno učenje. Spremembe v okoljski pismenosti učencev so se kazale v tem, da so učenci poudarjali pomembnost varovanja okolja in recikliranja, vendar pa vplivi na spremembe njihovega ravnanja niso bili zaznani. Učenje $z$ raziskovanjem $\mathrm{z}$ uporabo konteksta o življenjskem krogu izdelkov lahko učinkovito vpliva na motiviranost učencev in učne pristope $\mathrm{v}$ kemijskem izobraževanju, ki temeljijo na trajnostnem razvoju. V prihodnje bi bilo treba raziskati še vrste oblikovanega znanja, ki ga s tovrstnim izobraževanjem pridobijo dijaki ali učenci. Poleg tega pa bi morali uporabljati tudi druge pristope v poučevanju trajnostnega razvoja pri pouku kemije.

Ključne besede: odnosi; učenje kemije; okoljska pismenost; učenje z raziskovanjem; življenjski krog izdelka 


\section{Introduction}

"I understood how much even a small thing, such as a simple newspaper, impacts on everything. It is simple to manufacture it but still it consumes a lot. So the importance of recycling is huge. I mean, you need to recycle, otherwise nothing makes sense."

(a 15-year-old girl expressing her attitudes after the life-cycle project)

The rationale of the present design research is to improve Finnish students' attitudes and skills related to chemistry, sustainability and the materials of various products. The study addresses two separate concepts: chemistry attitudes and environmental literacy. The conclusion and discussion aim to determine the connection between these two concepts.

The research problem arises from the fact that throughout Europe the interest in key science subjects among young people has declined (Hofstein, Eilks, \& Bybee, 2010; the Inter Academy Panel, 2010; Krapp \& Prenzel, 2011; Osborne, 2003; Rocard, Csermely, Jorde, Lenzen, Walberg-Henriksson, \& Hemmo, 2007; Vassiliou, 2011). As in other European countries, national studies in Finland have revealed that Finnish students particularly dislike chemistry (Kärnä, Hakonen, \& Kuusela, 2012). The selection of topics and teaching methods are of key importance in supporting students' interest in studying science (Juuti, Lavonen, Uitto, \& Byman, 2009; Mandler, Mamlok-Naaman, Blonder, Yayon, \& Hofstein, 2012; Van Aalsvoort, 2004). Environmental and societal issues related to the daily lives of students can support their perception of the relevance of studying a certain subject (Mandler et al., 2012; Marks \& Eilks, 2009; Van Aalsvoort, 2004; Yager, Lim, \& Yager, 2006). In chemistry, Finnish students struggle the most with applied tasks related to various everyday materials (Kärnä, Hakonen, \& Kuusela, 2012). In response to this challenge, the present study applies inquiry-based chemistry teaching of life-cycle thinking to the upper-secondary school level.

From an educational point of view, life-cycle thinking is a socio-scientific teaching approach, as it is an interdisciplinary science issue that is complex, contradictory and relevant to the daily lives of students (Kolsto, 2001; Oulton, Dillon, \& Grace, 2004; Sadler, 2011). In terms of chemistry, it encompasses green chemistry and engineering (Anastas, \& Lankey, 2000; Askham, 2011). Analysing the comprehensive life cycle of a product is in itself an advanced field of science that evaluates the environmental burden of a product, investigating a process or activity by quantifying the net flows of different chemicals, materials and energy (Blackburn \& Payne, 2004). The assessment of resource use and 
emissions, as well as their health impacts, enables improvements to be made in product life-cycle processes from an environmental perspective (Anastas \& Lankey, 2000). Life-cycle thinking is a chemistry topic in the national standards of education in Finland (Ministry of Education, 2003, 2004).

Recently, the United Nations declared the years 2005-2014 the world decade on "Education for Sustainable Development" (UNESCO, 2009). The aim of this decade is to extend the ideal of sustainable development in all areas of education. Definitions of sustainability are widely discussed globally (Jerneck et al., 2011; Johnston, Everard, Santillo, \& Robèrt, 2007). In Finland, however, it is a worrying and problematic fact that boys have more negative attitudes towards environmental protection than girls (Asunta, 2003; Kärnä et al., 2012; Saloranta \& Uitto, 2010; Uitto et al., 2011). There is no doubt that future citizens must have the willingness and skills to act sustainably, whether in the role of a chemist, a consumer, a parent, a voter or a decision maker. Chemistry teaching can foster students' views on science-based sustainability issues. By using relevant and contradictory socio-scientific issues, it is possible to support students' understanding of how chemistry topics also reflect the moral, social and physical world around them (Holbrook, 2005; Zeidler, Sadler, Simmons, \& Howes, 2005; Wilmes \& Howarth, 2009).

The term 'environmental literacy' refers to the skills and motivation to work towards the resolution of environmental problems, and active involvement in working towards the maintenance of a dynamic equilibrium between the quality of life and the quality of the environment (Hsu \& Roth, 1998). It is related to knowledge, affect, skills and behaviour on three levels: nominal, functional and operational competences (Roth, 1992). UNESCO includes knowledge, understanding, attitudes and active involvement in their environmental literacy-related statements (Marcinkowski, 1991). The applications and objectives of environmental literacy are cross-curricular and closely related to the objectives of 'scientific literacy' (Holbrook \& Rannikmae, 2009; Simmons, 1989). In the present study, changes in students' environmental literacy are assessed in terms of environmentally responsible attitudes and pro-environmental behaviour (Yavez, Goldman, \& Peer, 2009; see also Erdogan, Marcinkowski, \& Ok, 2009). The intention to act - in other words, pro-environmental behaviour - is a powerful predictor of responsible environmental behaviour (Hsu \& Roth, 1998).

Combining life-cycle thinking and inquiry-based learning is a new approach to teaching chemistry. An inquiry-based learning setting was used because it had been shown to generate positive attitudes towards chemistry in students (Aksela, 2005; Gibson \& Chase, 2002; Juuti et al., 2009; Minner, Levy, \& Century, 2010; Rocard et al., 2007). Inquiry approaches place more of 
the responsibility for the task on students (Colburn, 200o). They can support individual decision-making processes and provoke socio-scientific discussion about topics such as consumer products (Marks \& Eilks, 2009). This learning setting is a new example of how to involve aspects of sustainability (Tundo et al., 2000) and ethics (Dondi, 2011; Zeidler et al., 2005) in chemistry lessons. Furthermore, this approach meets the goals of "education through science" thinking, as opposed to "education in science" thinking (see Holbrook \& Rannikmae, 2007).

\section{The research problem and the research question}

Chemistry textbooks in Finland lack tasks related to life-cycle thinking and inquiry (Juntunen \& Aksela, 2011). In order to support the work of teachers, in-service training courses about life-cycle thinking, inquiry-based teaching methods and sustainable development were arranged in Finland from 2010 to 2012 . At these courses, a total of 20 chemistry teachers collaboratively developed new inquiry-based, life-cycle thinking teaching models for their own needs (Joyce \& Weil, 1986; Juntunen \& Aksela, in review). The present case study, which is part of a larger cyclic design research project (Edelson, 2002), investigates students' perspectives on this novel teaching approach. In particular, the study investigates whether inquiry-based life-cycle teaching affects students' attitudes to studying chemistry and to behaving in an environmentally sustainable way. The research question was: How does an inquiry-based life-cycle thinking project in chemistry education affect students' chemistry attitudes and environmental literacy?

\section{Method}

\section{Participants}

The empirical research was conducted during the 2011-2012 school year in three schools in Southern Finland. The participants were 105 upper-secondary school students in the 9 th year (14-15 years), 58 of whom were girls and 47 boys. Their chemistry teachers $(\mathrm{N}=3)$ tested the novel approach to teaching life-cycle thinking. A researcher visited the three schools before and after the life-cycle project work and collected and analysed all of the data used in this study. Among the volunteers, 27 students were randomly chosen for interviews, which were documented on audio recordings. All of the other data collected was in a written form in surveys. The language used in the intervention was Finnish, but all of the answers presented in the present paper have been translated into English. 


\section{Intervention}

The intervention was a project work based on the inquiry-based, student-centred, social teaching model (see Colburn, 200o; Joyce \& Weil, 1986). The aim of the project was for students in small teams to consider the pros and cons of the life-cycle of a product. The students chose the product according to their own interest. During the project, the students were involved in setting their own research questions, searching for information, discussing their findings in teams, reviewing the work of other teams, and presenting the results. After the project, the students had an opportunity to engage in debate about their views regarding the usefulness of products, responsibility and the individual's possibilities for action. The students collected data about raw materials, manufacturing processes and usage, as well as recycling and waste management. In cases where the team of students was particularly capable, their investigations also included elements such as precise information or estimates about the product's lifespan, footprints, health effects and environmental impacts. Depending on the teacher, the student group and the product of interest, the intervention took about 10-15 hours over a period of 2-3 weeks. The content of the work was up to the students themselves; thus they learned to take responsibility of their own learning. Throughout the project, the role of a teacher was that of a facilitator, supporting the students with ideas whenever they needed help or encouragement.

\section{Research instruments}

A summary of the research instruments of the study is presented in Table 1 and explained in more detail below. On order to improve the validity of the results, mixed-methods and researcher-triangulation were used. Here, researcher-triangulation means that another researcher independently conducted a similar analysis of all of the data in order to validate the same results.

Table 1. Research Instruments

\begin{tabular}{l|l|l}
\hline & \multicolumn{1}{|c|}{ Chemistry Attitudes } & \multicolumn{1}{c}{ Environmental Literacy } \\
\hline $\begin{array}{l}\text { Before the } \\
\text { intervention (pre) }\end{array}$ & $\begin{array}{l}\text { Semi-structured interviews } \\
\text { (Marks, Bertram, \& Eilks, 2008) }\end{array}$ & $\begin{array}{l}\text { A survey (Yavez et al., 2009), } \\
\text { semi-structured interviews (Marks, } \\
\text { Bertram, \& Eilks, 2008) }\end{array}$ \\
\hline $\begin{array}{l}\text { After the } \\
\text { intervention (post) }\end{array}$ & $\begin{array}{l}\text { An open questionnaire (Eilks, } \\
\text { 2005; Marks et al., 2008), a sur- } \\
\text { vey (Marks et al., 2008), semi- } \\
\text { structured interviews (Marks, } \\
\text { Bertram, \& Eilks, 2008) }\end{array}$ & $\begin{array}{l}\text { An open questionnaire (Eilks, } \\
\text { 2005; Marks et al., 2008), a survey } \\
\text { (Yavez et al., 2009), semi-struc- } \\
\text { tured interviews (Marks, Bertram, } \\
\text { \& Eilks, 2008) }\end{array}$ \\
\hline
\end{tabular}


The students' chemistry attitudes were measured both qualitatively and quantitatively. Qualitative methods included pre-post semi-structured interviews (Marks, Bertram, \& Eilks, 2008) and an open post-questionnaire (Eilks, 2005). A quarter of the students $(\mathrm{N}=27)$ were interviewed in groups of 4-5 students directly before and after the intervention. Semi-structured questions were modified from Marks et al. (2008) and are presented in Table 2. The analysis of the discussions was content driven (Tuomi \& Sarajärvi, 2006), with students' answers being quantified according to their explicit expressions. The answers were classified in terms of:

(1) the students' reflective expressions about the usefulness or non-usefulness of studying chemistry,

(2) chemistry content.

Table 2. Semi-structured questions in the interviews

\begin{tabular}{l|l}
\hline Pre-Discussions & Post-Discussions \\
\hline $\begin{array}{l}\text { (1) What is the main content you learned in } \\
\text { your previous chemistry lessons? }\end{array}$ & $\begin{array}{l}\text { (6) Why do you think all students must } \\
\text { learn chemistry in school? }\end{array}$ \\
\hline $\begin{array}{l}\text { (2) What kind of working methods have you } \\
\text { used in chemistry lessons before? }\end{array}$ & $\begin{array}{l}\text { (7) How did this project work differ from the } \\
\text { usual lessons? }\end{array}$ \\
\hline $\begin{array}{l}\text { (3) How does an average chemistry lesson } \\
\text { take place? }\end{array}$ & $\begin{array}{l}\text { (8) In your opinion, what are the main } \\
\text { things you have learned? }\end{array}$ \\
\hline $\begin{array}{l}\text { (4) Did you learn something in your chem- } \\
\text { istry lessons that you can use at home or in } \\
\text { your free time? }\end{array}$ & $\begin{array}{l}\text { (9) In the last few weeks, you have learned } \\
\text { a lot about life-cycle thinking. Does this } \\
\text { make you think about products' life-cycles } \\
\text { in your free time as well? }\end{array}$ \\
\hline $\begin{array}{l}\text { (5) What do you want from chemistry les- } \\
\text { sons? }\end{array}$ & $\begin{array}{l}\text { (10) In the last few weeks, you have learned } \\
\text { a lot about life-cycle thinking. Does this } \\
\text { make you think about your behaviour as a } \\
\text { consumer? }\end{array}$ \\
\cline { 2 - 2 } & $\begin{array}{l}\text { (11) Do you think your behaviour could } \\
\text { change due to life-cycle thinking and the } \\
\text { project? }\end{array}$ \\
\hline
\end{tabular}

The four open written questions used after the intervention are presented in Table 3. The first three questions were the same as those of Eilks (2005), while the fourth question was added based on the pre-interviews (Marks et al., 2008). The answers $(\mathrm{N}=105)$ were content-analysed regarding how the students reflect the inquiry-based life-cycle thinking project overall, and whether they mention improvement in their communication abilities, cooperative skills and independent work (Eilks, 2005; Tuomi \& Sarajärvi, 2006). The answers were classified as positive, neutral or negative. Positive expressions included statements such as "I liked it", "I loved the freedom and studying like this", "It was 
fun", "Interesting to learn important things" or "Nice to be creative". Typical neutral answers included statements such as "It was just a different method of studying" or "No opinion", while negative expressions were those such as "The topic was boring", "I prefer the ordinary lessons", "Useless" or "Too much homework".

Table 3. The written open post-questionnaire (Eilks, 2005; Marks et al., 2008)

(1) What are the most important differences between this project and the chemistry lessons you normally have?

(2) What is your opinion on the approach based on your own questions and interest? What did you like the most about it, and what could be improved?

(3) Why do you think the teacher chose to use this approach for the last few lessons?

(4) What were the main things that you learned in this project?

The quantitative method to measure the students' chemistry attitudes was a 5-point Likert survey (Marks et al., 2008) administered after the intervention. The questionnaire asked students for their opinions about the content (questions 39-42) and methods (questions 37, 38, 43) of the life-cycle project, as well as their reflections on it (questions 34, 35, 36 and 44). The answers ( $\mathrm{N}=105)$ were analysed using basic statistical analysis. The questionnaire is presented in Appendix 1.

The students' environmental literacy was measured both qualitatively and quantitatively. Qualitative methods included pre-post semi-structured interviews (Marks et al., 2008) and an open post-questionnaire (Eilks, 2005; Marks et al., 2008). A quarter of the students $(\mathrm{N}=27)$ were interviewed in groups of 4-5 students directly before and after the intervention. The interview questions are presented in Table 2. The analysis of the discussions was content driven (Tuomi \& Sarajärvi, 2006). The students' answers were quantified according to their explicit expressions. Statements expressing environmental literacy were searched for in the analysis, and responses were classified in terms of their reflective expressions about:

(1) environmental and societal awareness,

(2) contradictory and confusing aspects,

(3) development of students' life-cycle thinking skills, consumer behaviour and environmentally responsible behaviour.

The four open written questions - asked only after the project work are presented in Table 3. The open answers $(\mathrm{N}=105)$ from the questionnaire regarding the students' environmental literacy were reflected in the analysis of Eilks (2005) and Marks et al. (2008), as well as being content analysed (Tuomi 
\& Sarajärvi, 2006). The answers' content-driven categories related to environmental literacy were new thoughts and the importance of environmental protection and recycling.

Environmental literacy, in terms of environmental attitudes and proenvironmental behaviour, was studied quantitatively with a pre-post 5-point Likert survey (Yavez et al., 2009). The original questionnaire from Yavez, Goldman, and Peer (2009) was a 4-point survey with 43 questions. Of these, 32 were modified to meet the goals of the present study. The environmental knowledge section was not considered as a suitable measurement instrument of environmental literacy for the present rather unstructured inquiry-based life-cycle project. For this reason, and in order to limit the amount of data, this section was omitted. A question about eating vegetarian food was included because the topics of environmental activism were broadened from housing and consumption to include food consumption as well. The main components that make up an individual's environmental footprint can be divided into four areas: housing, food, transport and the consumables we buy (Calcott \& Bull, 2007). Transportation was omitted from the present study. The environmental literacy survey used is presented in Appendix 2.

The quantitative answers of the students $(\mathrm{N}=96$, because 9 of the 105 answers could not be used) were analysed with SPSS (Statistical Package for Social Science, PASW Statistics 18) using basic statistical analysis, factor analysis and three-way ANOVA. It could have included three main effects, three twoway interactions and one three-way interaction, but here only the main effects (gender, pre/post, school) and the two-way interactions (between pre/post and gender or school) are of interest. Due to the fact that the reliabilities of the factor scores of the sum variables used by Yavez, Goldman, and Peer (2009) were weak (Cronbach's alpha between 0.49-0.82), factor analysis was used to obtain new factor scores, while the correlations of these scores to gender, school and pre/post-answers were investigated with three-way ANOVA. The extraction method was Principal Axis Factoring and the rotation method was Promax with Kaiser Normalisation. The pattern matrixes are shown in Tables 4 and 5. Questions 1-21 were iterated nine times. In order to create meaningful and reliable sum variables, a factor score limit of 0.4 was agreed upon amongst the researchers. Thus questions $1,3,4,5$ and 7 did not reliably fit into any sum variables and were omitted from subsequent analysis. New combinations of behaviour factor scores were named to measure environmentally responsible behaviour in daily life (questions 15, 18, 19, 20 and 21), citizenship actions in nature (questions 8, 11, 12, 16 and 17), resource conserving actions for personal financial benefit (questions 6, 9, 10 and 14) and recycling efforts (questions 2 and 13). The 
attitude questions from 22 to 36 were iterated three times. Here, only question 22 was omitted, as its factor score was less than 0.4 . The new sum variables were named as importance of environmental education, legislation and enforcement as a tool for environmental management (questions 24, 25, 27, 28, 30, 31 and 32) and locus of control and value of the natural environment (questions 23, 26, 29 and 33).

Table 4. The pattern matrix of the factor scores for pre-environmental action questions from 1 to 21, of which the new factors were created using a limit of value 0.4

\begin{tabular}{l|l|l|l|l|l}
\hline \multirow{2}{*}{} & \multicolumn{5}{|c}{ Factor } \\
\hline & 1 & 2 & 3 & 4 & 5 \\
\hline 15 & .618 & & & & \\
\hline 20 & .551 & & & & \\
\hline 18 & .549 & & & & \\
\hline 21 & .486 & & & & \\
\hline 19 & .481 & & & & \\
\hline 7 & .360 & & & & \\
\hline 1 & -.339 & & -.309 & & \\
\hline 16 & & .574 & & & \\
\hline 17 & & .537 & & & \\
\hline 11 & & .512 & & & \\
\hline 8 & & .495 & & & \\
\hline 12 & & -.476 & & & \\
\hline 3 & & .381 & & & \\
\hline 5 & & .293 & & & \\
\hline 9 & & & .678 & & \\
\hline 14 & & & -.605 & & \\
\hline 10 & & & .489 & & \\
\hline 6 & & & -.406 & & \\
\hline 13 & & & & .734 & \\
\hline 2 & & & & .667 & \\
\hline 4 & & & & & .703 \\
\hline
\end{tabular}

Table 5. The pattern matrix ${ }^{a}$ factor scores for the attitude questions from 22 to 33, of which the new factors were created using a limit of value 0.4

\begin{tabular}{c|c|c}
\hline \multirow{2}{*}{} & \multicolumn{2}{|c}{ Factor } \\
\cline { 2 - 3 } & 1 & $\mathbf{2}$ \\
\hline 27 & .667 & \\
\hline 25 & .653 & \\
\hline 28 & .635 & \\
\hline 32 & .630 & \\
\hline 24 & .593 & \\
\hline 31 & .568 & \\
\hline 30 & .524 & \\
\hline 26 & & .714 \\
\hline 33 & & .614 \\
\hline 29 & & .436 \\
\hline 23 & & .403 \\
\hline 22 & .302 & -.303 \\
\hline
\end{tabular}




\section{Results}

\section{Chemistry attitudes}

The students' chemistry attitudes developed in a positive direction. In the interviews conducted after the intervention, every single one of the students reflected the usefulness of studying chemistry by expressing how they learn beneficial things in chemistry. More than a third of them $(\mathrm{N}=11 / 27)$ mentioned the common knowledge role of chemistry literacy as being important to them. The content students described learning in chemistry switched from chemical presentations to substances in various products. In the four open written questions, students mentioned the improvement in their communicative abilities (half of the students, $\mathrm{N}=53 / 105$ ), independent working (a third of the students, $\mathrm{N}=36 / 105$ ) and cooperative skills (a seventh of the students, $\mathrm{N}=15 / 105)$. Overall, they reflected the inquiry-based life-cycle thinking project in a very positive way. Similarly, the survey showed that the study methods of the project appealed to both girls and boys, with girls rating the content of the project and the concept of life-cycle thinking more positively than boys.

A more detailed examination of the interviews' content analysis reveals that the students' reflective expressions about studying chemistry turned from non-usefulness to usefulness. Prior to the project, many students expressed cautious thoughts in the interviews: "Ive learned to be careful with substances", "I'm afraid to apply chemistry in my free time", "You can make holes in your skin". After the project, more than a third of the interviewed students $(\mathrm{N}=11 / 27)$ mentioned the common knowledge role of chemistry literacy. They again described a few dangers, such as toxics at home or unhealthy, nature-harming substances; however, all of them started to describe how they also learn beneficial things in chemistry: "What you use... What the products include... So that you will not use it the wrong way... How it is produced... What saves the environment and what does not... Important for your future plans...". The content knowledge in the project was clearly more interesting to them because it was related to their daily-life and sustainability issues. Prior to the project, the students described the chemistry content knowledge they had learned as atoms, ions, molecular presentations, reactions or chemical symbols, and substances and their combination in their chemistry lessons. The only experimental work they remembered was "elephant's toothpaste and liquorice". According to all of the students, the typical working method was writing and reading or doing assignments from books. They reported that a typical chemistry lesson involved "doing some theory first" and "listening to your teachers rant", followed by talking, doing experiments and writing "like crazy" in a notebook. The students wanted 
to have more experiments and less writing in their chemistry lessons. After the project, the content knowledge they mentioned was substances in various products. The students explained that they had learned about plastics in a computer mouse, substances of a circuit board, substances of an anti-ageing face cream, carbon fibres in an ice hockey stick, and chemicals in a lipstick. In comparison to ordinary chemistry lessons, the students described the life-cycle project as: "More meaningful and free, nicer, and funnier" and "you could influence the methods of how to study, you learned better, it was not so boring". This was mainly because they had a chance to "share opinions, cooperate, search the Internet and books, make phone calls". Students said: "When you search for the information yourself... You choose... You find more diverse knowledge... You are responsible for your own actions... You do not need to only listen to ranting... You can do something yourself... You get straight feedback". One of the students described the project work: "You yourself see the result of what you've managed to do... I mean, the ordinary weekly lessons don't tell us everything. As you have to do everything yourself from the beginning to the end, you really see the result and how much you know about it after all - in comparison to only answering some questions in your notebook...”. Thus the inquiry-based, independent and social learning setting undoubtedly motivated the students in studying chemistry.

The answers to the four open written questions in the survey are presented in Table 6. Content analysis of the answers shows that the students $(\mathrm{N}=105)$ reflected the inquiry-based life-cycle thinking project in a generally positive way $(\mathrm{N}=85 / 105)$, with girls being more positive than boys. Only a few students $(\mathrm{N}=7 / 105)$ had negative attitudes towards the project. They would have liked to have more time for their investigations. Also, open-ended assignment instruction caused some confusion, and students asked for more explicit guidelines. The improvement in communication abilities in environmental discourse was reflected by almost half of the students $(\mathrm{N}=53 / 105)$. They perceived improvements in their critical thinking skills: "We can criticise the facts", "Most of the information about the product manufacturing was hidden", "We had a chance to state our opinion and hear those of others". Independent learning or working was mentioned in a positive way by about a third of the students $(\mathrm{N}=36 / 105)$ : "More free", "Encouraged to search for information independently", "You can investigate what you want", "It is good to look at a subject from different perspectives and angles", "Own work", "You took responsibility for yourself", "You could search for the information creatively". Cooperative skills were positively discussed by about every seventh student ( $\mathrm{N}=15 / 105)$ : "The best thing was to work with a friend", "You learned to cooperate", "As you study together, you discuss your work and get different opinions about it", "It was interesting to learn what other groups had 
learned". The inquiry-based, independent and social learning setting encouraged improvements in the students' communicative abilities, critical thinking skills and cooperative skills.

Table 6. The results of the content analysis of written open answers

\begin{tabular}{l|c|c}
\hline Category, where an answer was classified & girls $(\mathrm{N}=58)$ & boys $(\mathrm{N}=\mathbf{4 7})$ \\
\hline Independent learning & 27 & 9 \\
\hline Cooperative learning & 10 & 5 \\
\hline Communication abilities & 31 & 22 \\
\hline Positive attitude in general towards the project & 53 & 32 \\
\hline Neutral attitude in general towards the project & 2 & 11 \\
\hline Negative attitude in general towards the project & 3 & 4 \\
\hline
\end{tabular}

The results of the quantitative survey (Appendix 1) are in line with the results from the interviews and open written questions. The students' opinions about life-cycle thinking, the content of the project and the study methods were statistically evaluated after the intervention. The means and standard deviations of the girls and boys are shown in Table 7. A response with the value 1 corresponds to "strongly disagree", while 5 means "strongly agree". The girls positively reflected product life-cycle thinking (questions 1, 2, 3 and 11, mean = 3.6) and the content of the project (questions 5, 6 and 10, mean 3.9), whereas the boys were neutral (both means $=3.0$ ). The study methods appealed to both girls (questions 6, 7, 8 and 9, mean $=4.1$ ) and boys $($ mean $=3.8)$.

Table 7. The means and standard deviations of the girls and boys studied

\begin{tabular}{l|c|c|c|c}
\hline \multirow{2}{*}{ Project evaluation } & \multicolumn{2}{|c|}{ Girls (N=58) } & \multicolumn{2}{c}{ Boys (N=47) } \\
\cline { 2 - 5 } & Mean & SD & Mean & SD \\
\hline Reflection & 3.6 & 0.9 & 3.0 & 1.0 \\
\hline Content & 3.9 & 0.9 & 3.0 & 1.1 \\
\hline Study methods & 4.1 & 0.9 & 3.8 & 1.0 \\
\hline
\end{tabular}

\section{Environmental literacy}

In the interviews held prior to the intervention, the students did not mention anything related to environmental literacy aspects. After the intervention, they positively reflected the development of their life-cycle thinking skills $(\mathrm{N}=13 / 27)$ and consumer behaviour $(\mathrm{N}=9 / 27)$. Nonetheless, almost half 
of the students $(\mathrm{N}=12 / 27)$ did not think that the project had affected their own environmentally responsible behaviour. The majority of them did, however, think that this type of project could influence other young peoples' behaviour $(\mathrm{N}=17 / 27)$. In the four open written questions, almost every student $(\mathrm{N}=82 / 105)$ mentioned that the most important outcome for them was new ideas and realisations. In responding to the survey, they extensively expressed the importance of environmental protection or recycling. In the quantitative survey results, no significant $(\mathrm{p}<0.01)$ differences in students' environmental attitudes or behaviour were noticed.

A more detailed examination of the interview answers reveals that students' environmental and societal awareness increased clearly, as the most important things the students said they had learned were societal: "It is not just that the product is manufactured and used, but that it includes all forms and everything, transportation, paper work and cultivation... It made me think about what to buy and how you affect this system." A third of the students $(\mathrm{N}=9 / 27)$ thought that the project influenced the depth of their life-cycle thinking and consumption habits to some extent: "I try to save energy... I've started to think about my water consumption... You think what you waste and what you save." Almost all of the students described the importance of recycling: "If you do not recycle, what happens, it can take decades before it combusts... So the main point must have been that you have to recycle... We looked at the two ways - either to recycle or not - and there was a huge difference!". The contradictory aspects that the students observed were in the limited openness of information, in health claims, or in the pros and cons of manufacturing processes in the countries of production. In terms of the development of life-cycle thinking skills, consumer behaviour and environmentally responsible behaviour, the results show that almost half of the students $(\mathrm{N}=12 / 27)$ stated that the life-cycle project did not make them think about their consumption habits or products' life-cycles during their free time: "Not much... If you just buy from a shop you don't think about how it has affected the Earth or ended up here." Mostly students were confused about the extensiveness of life-cycle thinking: "I started to think about other products at home too, but then I couldn't. I didn't know what had really happened, so I let it be..." Still, the majority of the students $(\mathrm{N}=17 / 27)$ believed that in general their behaviour, or that of other young people, could change because of school projects: "If students discuss it themselves, it will matter.. If parents tell their children to recycle they won't do it, but if it's their friend it affects them more... So the clever ones will learn it... If the project continued long enough, people would start to care more and more, even though there are always people who won't care". Some of the students were also sceptical: "We are being raised to 
this easiness... It all comes from a shop, if you started to study it more, you would end up cultivating your own garden, its seeds and a cow to get fertilisers". The intervention caused reflective thinking about the individual's action skills and the life-cycles of products. A third of the students had positive thoughts about their own environmentally responsible behaviour. Almost half of them could not see any change in their own behaviour, but thought that this type of project could influence the behaviour of others.

The answers to the four open written questions in the survey supported the results of the interviews. Most students $(\mathrm{N}=82 / 105)$ wrote that the most important outcome for them was somehow new scientific thoughts about the world: "Simple things are more complex than they look", "You need many things to manufacture even a small product" "I started to think about Earth issues." The importance of environmental protection and recycling was extensively reflected: "We discussed raw materials more than usual", "How many chemicals and how much hidden water the manufacturing of products consumes", "The life cycles of different products look alike", "I know better now how the birth of a product oppresses nature", "Too many things are being used, so we overload".

The quantitative survey results did not show any changes in students' environmental literacy in terms of attitudes or pro-environmental behaviour. Furthermore, the life-cycle project did not cause any significant $(\mathrm{p}<0.01)$ pre/post differences in the results of the 5-point Likert survey (Appendix 2). In order to analyse the correlations of gender, school and pre/post answers to the environmental literacy sum factors, three-way ANOVA was used. The main effects (gender =sp, pre/post and school = koulu) and two of the two-way interactions (between pre/post and gender or school) were analysed. In factor 1 (questions $15,18,19,20,21$ ), factor 2 (questions $8,11,12,16,17$ ) and factor 5 (questions 24, 25, $27,28,30,31,32)$, gender and school both had a significant main effect. In factor 6 (questions 23, 26, 29, 33), only gender had a significant main effect. In factor 3 (questions 6, 9, 10, 14) and factor 4 (questions 2, 13), there were no significant main effects. There were no significant two-way interaction effects in any of the factors, meaning there were no pre/post-effects related to gender or school. Along with gender, school culture and practice seemed to strongly influence the students' environmental literacy. The girls' behaviour and attitude scores in the survey were more environmentally responsible than those of the boys, both before and after the intervention. Furthermore, the students' environmental attitude scores were generally more positive than their pro-environmental behaviour scores. The reliabilities of the sum factors as Cronbach's alphas are shown in Table 8, which also shows the reliabilities for all behaviour questions (1-21) and for all attitude questions (22-33). The values are good enough to conclude 
that the survey was consistent. This means that the differences appeared due to the students being different, not because of confusing or unclear questions.

Table 8. The Cronbach's alphas for the sum factors

\begin{tabular}{l|l}
\hline factor 1 = Environmentally responsible behaviour in daily life & 0.703 \\
\hline factor 2 = Citizenship action in nature & 0.674 \\
\hline factor 3 = Resource conserving actions with personal financial benefit & $0.091^{*}$ \\
\hline factor 4 = Recycling efforts & 0.651 \\
\hline $\begin{array}{l}\text { factor } 5 \text { = Importance of environmental education, legislation and enforcement } \\
\text { as a tool for environmental management }\end{array}$ & 0.799 \\
\hline factor 6 = Locus of control and value of the natural environment & 0.624 \\
\hline All behaviour questions & 0.828 \\
\hline All attitude questions & 0.789 \\
\hline
\end{tabular}

* If question 6 is omitted, the Cronbach's alpha is 0.643 .

\section{Discussion and conclusions}

The results indicate that inquiry-based life-cycle study has positive effects on students' attitudes towards chemistry and environmental literacy. The students valued the novel chemistry learning setting, which was very independent but still collaborative. The approach is a clear example of more motivating and sustainable chemistry education.

The results are in line with previous evidence. The low interest in studying chemistry (Kärnä et al., 2012) could be transformed into interest by using more relevant topics and teaching methods (see also Juuti et al., 2009 and Van Aalsvoort, 2004). According to the students, the sustainability aspects in the project motivated them to study. The environmental and societal issues related to the daily lives of the students increased their sense of the relevance of chemistry (see Mandler et al., 2012; Marks \& Eilks, 2009; Van Aalsvoort, 2004; Yager et al., 2006). After the life-cycle project, many of the students started to see chemistry as a subject that supports general knowledge or general literacy. All of the students interviewed stated that they had learned beneficial things about substances and products in the chemistry lessons. They described the project as more meaningful and diverse than their ordinary chemistry lessons, which most often include only writing and listening to the teacher's lectures. Their previously cautious thoughts regarding using chemistry in their daily life became more environmentally orientated. 
The inquiry-based learning methods employed generated positive chemistry attitudes in students, as was expected and previously observed (e.g., Aksela, 2005; Gibson \& Chase, 2002; Juuti et al., 2009; Minner et al., 2010; Rocard et al., 2007). As in the findings of Juuti et al. (2009), girls liked the inquiry-based methods more than boys. Most students noticed improvement, especially in their communication abilities or critical thinking skills.

This type of studying clearly generates socio-scientific thinking and student-driven discussions in the classroom. The most important outcome of the project for the students was the new perspectives and realisations. A third of the students stated that the project had had an influence on the depth of their lifecycle thinking and consumption. However, many students were confused about the extensiveness of life-cycle thinking and saw contradictory aspects in the quality of information from different stakeholders. Although there was some scepticism, the majority of the students interviewed believed that in general their own behaviour, or that of other young people, could change due to this type of project. Almost all of the students addressed the importance of environmental protection, especially recycling. This is understandable, as recycling is generally the sustainability theme that students are the most familiar with (Asunta, 2003; Tung, Huang, \& Kawata, 2002).

Even though expressions of environmental awareness and societal views increased significantly, quantitatively significant changes in environmentally oriented behaviour or attitudes were not induced. This may be due to the fact that changes in attitudes and behaviour are a personal, and often slow, process (Dwyer, Leeming, Cobern, Porter, \& Jackson, 1993). Gender seemed to affect the students' environmental literacy significantly, as found in previous research (e.g., Bogner \& Wiseman, 1999; Tikka, Kuitunen, \& Tynys, 20oo; Uitto, Juuti, Lavonen, Byman, \& Meisalo, 2011), with girls scoring better than boys in this area. Generally, the students' environmental attitudes appeared to be more positive than their pro-environmental behaviour, which is also in line with earlier research (e.g., Erdogan \& Ok, 2011).

The results are encouraging. The project was short, but it positively affected the students' chemistry attitudes and successfully planted the important seeds of environmental literacy. The students' new realisations indicate that their personal process of attitude and behavioural change has started. There were also significant differences between schools. For the teacher, it is motivating to know that school culture can affect students' environmental literacy (see Erdogan, Marcinkowski, \& Ok, 2009).

To conclude, the results support the evidence that teaching life-cycle thinking using inquiry-based methods is a sound option for improving students' 
chemistry attitudes and environmental literacy. It is an example of how to create a necessary, meaningful and interdisciplinary link between chemistry lessons, sustainability issues, ethics and the daily lives of students. More research is needed to investigate the kind of knowledge outcomes this type of teaching creates. In order to achieve the goals of sustainable development (UNESCO, 2009; Johnston, Everard, Santillo, \& Robèrt, 2007), further research should also investigate the range of other advisable approaches that chemistry teachers use when teaching sustainable development. To change the world, education that genuinely changes behaviour should be found.

\section{Acknowledgements}

We would like to acknowledge the Research Foundation of the University of Helsinki and the association Maa- ja vesitektiikan tuki ry. for their financial support.

\section{References}

Aksela, M. (2005). Supporting meaningful chemistry learning and high-order thinking through computer-assisted inquiry: A design research approach. Helsinki: University Print.

Anastas, P., \& Lankey, R. (2000). Life cycle assessment and green chemistry: the yin and yang of industrial ecology. Green Chemistry, 2(6), 289-295.

Asunta, T. (2003). Knowledge of environmental issues: where pupils acquire information and how it affects their attitudes, opinions, and laboratory behaviour. Jyväskylä: University Print.

Blackburn, R. S., \& Payne, J. D. (2004). Life cycle analysis of cotton towels: impact of domestic laundering and recommendations for extending periods between washing. Green Chemistry, 6(7), $59-61$.

Bogner, F. X., \& Wiseman, M. (1999). Toward measuring adolescent environmental perception. European Psychologist, 4(3), 139-151.

Calcott, A., \& Bull, J. (2007). Carbon Plan, WWF UK: Ecological Footprint of British city residents. Retrieved January 25 2013, from http://assets.wwf.org.uk/downloads/city_footprint2.pdf Colburn, A. (2000). An inquiry primer. Science scope, 23(6), 42-44.

Dondi, F. (2011). Ethics in chemical education: Towards the culture of responsibility. Article presented at the conference "The Concept of Responsibility: Ethics, Chemistry and the Environment", Modena, Italy.

Dwyer, W., Leeming, F., Cobern, M., Porter, B., \& Jackson, J. (1993). Critical review of behavioural interventions to preserve the environment: Research since 1980. Environment and Behaviour, 25(3), 275-321.

Edelson, D. (2002). Design research: What we learn when we engage in design. Journal of Learning 
Science, 11(1), 105-121.

Eilks, I. (2005) Experiences and reflections about teaching atomic structure in a jigsaw classroom in lower secondary chemistry lessons. Journal of Chemical Education, 82(2), 313-319.

Erdogan, M., Marcinkowski, T., \& Ok, A. (2009). Content analysis of selected features of K-8 environmental education research studies in Turkey, 1997-2007. Environmental Education Research, 15(5), 525-548.

Erdogan, M., \& Ok, A. (2011). An assessment of Turkish young pupils' environmental literacy: A nationwide survey. International Journal of Science Education, 33(17), 2375-2406.

Gibson, H. L., \& Chase, C. C. (2002). Longitudinal impact of an inquiry-based science program on middle school students' attitudes toward science. Science Education, 86(5), 693-705.

Hofstein, A., Eilks, I., \& Bybee, R. (2010). Societal issues and their importance for contemporary science education - a pedagogical justification and the-state-of-art in Israel, Germany, and the USA. International Journal of Science and Mathematics Education, 9(6), 1459-1483.

Holbrook, J. (2005), Making chemistry teaching relevant. Chemical Education International, 6(1). Retrieved January 25 2013, from http://old.iupac.org/publications/cei/vol6/o6_Holbrook.pdf Holbrook, J., \& Rannikmae, M. (2007). The nature of science education for enhancing scientific literacy. International Journal of Science Education, 29(11), 1347-1362.

Holbrook, J., \& Rannikmae, M. (2009). The meaning of scientific literacy. International Journal of Science Education, 4(3), 275-288.

Hsu, S.-J., \& Roth, R. E. (1998). An assessment of environmental literacy and analysis of predictors of responsible environmental behaviour held by secondary teachers in the Hualien area of Taiwan. Environmental Education Research, 4(3), 229-250.

the Inter Academy Panel (2010). Taking inquiry-based science education (IBSE) into secondary education. York: National Science Learning Centre, University of York. Retrieved January 25 2013, from http://www.allea.org/Content/ALLEA/WG\%20Science\%2oEducation/ProgrammeIBSE_YORK. pdf

Jerneck, A., Olsson, L., Ness, B., Anderberg, S., Baier, M., Clark, E., Hickler, T., Hornborg, A., Kronsell, A., Lövbrand, E., \& Persson, J. (2011). Structuring sustainability science. Sustainability Science, 6, 69-82.

Johnston, P., Everard, M., Santillo, D., \& Robèrt, K.-H., (2007). Reclaiming the Definition of Sustainability. Environmental Science and Pollution Research, 14(1), 60-66.

Juntunen, M., \& Aksela, M. (2011). Life-cycle thinking and inquiry-based learning in chemistry education. In M. Aksela, J. Pernaa, \& M. Happonen (Eds.), Inquiry methods to chemistry teaching: IV National chemistry education days - a symposium web book (pp. 110-121). Retrieved January 252013 , from http://www.helsinki.fi/kemma/data/kop-2011.pdf Juntunen, M., \& Aksela, M. (in review). Life-cycle thinking and inquiry-based learning in chemistry teaching.

Joyce, B., \& Weil, M. (1986). Models of teaching. New Jersey: Prentice Hall, Inc.

Juuti, K., Lavonen, J., Uitto, A., \& Byman, R. (2009). Science teaching methods preferred by grade 9 
students in Finland. International Journal of Science and Mathematics Education, 8(4), 611-632. Keys, C., \& Bryan, L. (2001). Co-constructing inquiry-based science with teachers: Essential research for lasting reform. Journal of Research in Science Teaching, 38(6), 631-645.

Kolsto, S. (2001). Scientific literacy for citizenship: Tools for dealing with the science dimension of controversial socioscientific issues. Science Education, 85(3), 291-310.

Krapp, A., \& Prenzel, M. (2011). Research on interest in science: theories, methods, and findings. International Journal of Science Education, 33(1), 27-50.

Kärnä, P., Hakonen, R., \& Kuusela, J. (2012). Science knowledge and skills at the $9^{\text {th }}$ class in 2011.

Observation report of education, 2, Ministry of Education. Tampere: University Press.

Mandler, D., Mamlok-Naaman, R., Blonder, R., Yayon, M., \& Hofstein, A. (2012). High-school chemistry teaching through environmentally oriented curricula. Chemistry Education Research and Practice, 13(2), 80-92.

Marcinkowski, T. (1991) The relationship between environmental literacy and responsible environmental behavior in environmental education. In M. Maldagle (Ed.), Methods and Techniques for Evaluating Environmental Education. Paris: UNESCO.

Marks, R., Bertram, S., \& Eilks, I. (2008). Learning chemistry and beyond with lesson plan on potato crisps, which follows a socio-critical and problem-oriented approach to chemistry lessons - a case study. Chemistry Education Research and Practice, 9(3), 267-276.

Marks, R., \& Eilks, I. (2009). Promoting Scientific Literacy Using a Sociocritical and ProblemOriented Approach to Chemistry Teaching: Concept, Examples, Experiences. International Journal of Environmental \& Science Education, 4(3), 231-245.

Minner, D. D., Levy, A. J., \& Century, J. (2010). Inquiry-based science instruction - What is it and does it matter? Results from a research synthesis year 1984 to 2002. Journal of Research in Science Teaching, 47(4), 474-496.

Osborne, J. (2003). Attitudes towards science: a review of the literature and its implications. International Journal of Science Education, 25(9), 1049-1079.

Oulton, C., Dillon, J., \& Grace, M. M. (2004). Reconceptualizing the teaching of controversial issues. International Journal of Science Education, 26(4), 411-423.

Rocard, M., Csermely, P., Jorde, D., Lenzen, D., Walberg-Henriksson, H., \& Hemmo, V. (2007).

Science Education Now: A renewed pedagogy for the future of Europe. Brussels: European Commission Directorate-General for Research Science, Economy and Society. Retrieved January 25 2013, from http://ec.europa.eu/research/science-society/document_library/pdf_o6/report-rocard-on-scienceeducation_en.pdf

Roth, C. E. (1992). Environmental Literacy: Its Roots, Evolution, and Directions in the 1990 .

Columbus: ERIC/CSMEE Publications.

Sadler, T. D. (2011). Socio-scientific issues-based education: What we know about science education in the context of SSI. In T. D. Sadler (Ed.), Socio-scientific issues in classroom: teaching, learning and research (pp. 355-369). New York: Springer.

Saloranta, S., \& Uitto, A. (2010). Oppilaan koulukokemusten yhteys ympäristöasenteisiin ja 
ympäristövastuulliseen käyttäytymiseen. In H. Risku-Norja, E. Jeronen, S. Kurppa, M. Mikkola, \& A. Uitto (Eds.), [Food - The requirement and the asset in teaching] (pp. 33-47). Helsinki: Ruraliainstitute.

Simmons, D. A. (1989). More infusion confusion: A look at environmental education curriculum materials. Journal of Environmental Education, 2o(4), 15-18.

Tikka, P. M., Kuitunen, M. T., \& Tynys, S. M. (200o). Effects of educational background on students' attitudes, activity levels, and knowledge concerning the environment. The Journal of Environmental Education, 31(3), 12-19.

Tuomi, J., \& Sarajärvi, A. (2006). Laadullinen tutkimus ja sisällönanalyysi [Qualitative research and content analysis]. Jyväskylä: Gummerus Printing House Oy.

Tundo, P., Anastas, P., Black, D., Breen, J., Collins, T., Memoli, S., Miyamoto, J., Polyakoff, M., \& Tumas, W. (2000). Synthetic pathways and processes in green chemistry. Introductory overview. Pure Applied Chemistry, 72(7), 1207-1228.

Tung, C., Huang, C., \& Kawata, C. (2002). The effects of different environmental education programs on the environmental behaviour of seventh-grade students and related factors. Journal of Environmental Health, 64(7), 24-29.

Uitto, A., Juuti, K., Lavonen, J., Byman, R., \& Meisalo, V. (2011). Secondary school students' interests, attitudes and values concerning school science related to environmental issues in Finland. Environmental Education Research, 17(2), 167-186.

UNESCO (2009). United Nations Decade of Education for Sustainable Development (DESD 20052014). Review of Contexts and Structures for Education for sustainable Development Learning for a sustainable world. Paris: UNESCO.

Van Aalsvoort, J. (2004). Activity theory as a tool to address the problem of chemistry's lack of relevance in secondary school chemical education. International Journal of Science Education, 26(13), $1635-1651$.

Vassiliou, A. (2011). Education in Europe: National Policies, Science Practices and research. European Commission Education, Audiovisual and Culture Executive Agency. Retrieved January 25 2013, from http://eacea.ec.europa.eu/education/eurydice/documents/thematic_reports/133EN.pdf

Wilmes, S., \& Howarth, J. (2009). Using issues-based science in the classroom. The Science Teacher, 76(7), 24-29.

Yager, S. O., Lim, G., \& Yager, R. E. (2006). The advantages of an STS approach over a typical textbook dominated approach in middle school science. School science and Mathematics, 106(5), $248-260$.

Yavez, B., Goldman, D., \& Peer, S. (2009). Environmental literacy of pre-service teachers in Israel: a comparison between at the onset and end of their studies. Environmental Education Research, 15(4), $393-415$.

Zeidler, D., Sadler, T., Simmons, M., \& Howes, E. (2005). Beyond STS: A research-based frame work for socio-scientific issues education. Science Education, 89(3), 357-376. 
Appendix 1. The attitude survey given to students after the intervention

How did you like the life-cycle project? (Mark the column that best describes your opinion with an " $\mathrm{x}$ " : strongly agree, agree, have no opinion, disagree, strongly disagree)

1. The project made me think about my consumption habits.

2. I now consider products differently than before the project.

3. I understood what the discussion about increasing sustainability is about.

4. I liked the project because it did not only deal with 'chemical content'.

5. I liked the project because it dealt with things that are interesting to me personally.

6. I liked the project because I got to work together with my classmates.

7. By using a range of methods, chemistry lessons become more interesting.

8. I did not like the project because I learned nothing from it.

9. I did not like the project because I had to read too much.

10. I did not like the project because it dealt too little with chemical content and experiments.

11. My view on products' life-cycles did not change.

Appendix 2. The environmental literacy survey given to students before and after the intervention

How often do you conduct the following activities? (Mark the column that best describes your opinion with an " $\mathrm{x}$ ": always, very often, sometimes, very seldom, never)

1. Stay silent and indifferent with regard to environmental problems.

2. Bring newspapers, cans, etc. to recycling collection points.

3. Write messages to (social) media on environmental problems.

4. Throw beverage cans and bottles into mixed waste.

5. Re-use used writing paper as draft paper.

6. Use plastic bags only once.

7. Purchase 'environmentally friendly' products (such as: ecologically farmed food, products with recyclable packaging, economy size products).

8. Collect things that people have thrown away in public areas and dispose of them in rubbish bins.

9. Conserve energy by turning off lights and electric appliances when not in use.

10. Conserve water at home (close faucet when brushing teeth, washing dishes, etc.). 
11. Comment to people who throw rubbish in a public place or damage the environment in any manner.

12. Leave rubbish (that people have thrown away) in the natural environment.

13. Dispose of used batteries in a proper collection container instead of a wastebasket.

14. Leave the TV on when I leave the room.

15. When I'm outside I notice the birds singing, animals and flowers.

16. Take part in campaigns for prevention of environmental damage (money collections, petitions, demonstrations, etc.).

17. I (or somebody in my family) belong to an environmental organisation.

18. Read articles on environmental issues in magazines and social media.

19. Watch programmes on nature and the environment on TV.

20. ake walks and trips in natural environments.

21. Eat vegetarian food.

To what extent do you agree with the following statements? (Mark the column that best describes your opinion with an " $x$ ": strongly agree, agree, have no opinion, disagree, strongly disagree)

22. I can contribute to the quality of the environment through my personal behaviour.

23. There is no use in trying to influence my family or friends regarding environmental issues.

24. If I had more knowledge I would integrate environmental considerations into my daily habits.

25. It is everyone's responsibility to take care of the environment.

26. Even if I save water or energy or purchase environmentally friendly products, it won't make any difference because the influence of other people is too great.

27. It is important to study environmental subjects and values in school.

28. Environmental topics should get higher priority in teaching than they do at present.

29. It is humankind's right to exploit natural resources (wood, oil, minerals, etc.) according to their needs without restrictions.

30. Factories should be penalised for environmental damage.

31. Private people should be penalised for environmental damage.

32. Industry should be forced to reduce pollutant emissions, even if this entails higher consumer prices.

33. The value of living creatures in nature is determined solely by their use for humanity. 


\section{Biographical note}

Maija Aksela, Professor, PhD, is both the head of the Unit of Chemistry Teacher Education Unit and of Finland's Science Education Centre in University of Helsinki, Finland. Her research interests are, for example teacher education, sustainable education and inquiry-based learning. She has written over 260 publications in science education.

Marianne Juntunen, M.Sc., M.Tech., is a chemistry teacher currently doing her PhD about Sustainability in Chemistry Education in University of Helsinki, Finland. Her main research interests are related to socio-scientific and sustainability issues in education. She teaches in a small school in NorthernLapland and volunteers for NGOs. 